Article

\title{
Combined Supplementation of Nano-Zinc Oxide and Thyme Oil Improves the Nutrient Digestibility and Reproductive Fertility in the Male Californian Rabbits
}

\author{
Ahmed A. A. Abdel-Wareth ${ }^{1}{ }^{1}$, Mohammed Ali Al-Kahtani ${ }^{2}$, Khalid Mushabab Alsyaad ${ }^{2,3}$, \\ Fatma Mohsen Shalaby ${ }^{2,4}$, Islam M. Saadeldin 5,6 (D), Fahdah Ayed Alshammari ${ }^{7}$, \\ Muhammad Mobashar ${ }^{8}$, Mohamed H. A. Suleiman ${ }^{9}{ }^{\mathbb{D}}$, Abdalla H. H. Ali ${ }^{1}$, \\ Mohamed O. Taqi ${ }^{10}$ (D), Hazem G. M. El-Sayed ${ }^{11}$, Mahmoud S. Abd El-Sadek ${ }^{12}$, \\ Abdallah E. Metwally ${ }^{13}$ and Ahmed Ezzat Ahmed 2,14,*(D) \\ 1 Department of Animal and Poultry Production, Faculty of Agriculture, South Valley University, \\ Qena 83523, Egypt; A.wareth@agr.svu.edu.eg (A.A.A.A.-W.); attai73@yahoo.com (A.H.H.A.) \\ 2 Department of Biology, College of Science, King Khalid University, Abha 61413, Saudi Arabia; \\ dr.malkahtani@gmail.com (M.A.A.-K.); alsyaad55@hotmail.com (K.M.A.); fshalabi@kku.edu.sa (F.M.S.) \\ 3 Director of Research Centre, College of Science, King Khalid University, Abha 61413, Saudi Arabia \\ 4 Department of Zoology, Faculty of Sciences, Mansoura University, 35516 Mansoura, Egypt \\ 5 Department of Physiology, Faculty of Veterinary Medicine, Zagazig University, Zagazig 44519, Egypt; \\ isaadeldin@ksu.edu.sa \\ 6 Department of Animal Production, College of Food and Agricultural Science, King Saud University, \\ Riyadh 11451, Saudi Arabia \\ 7 Department of Biology, College of Sciences and Literature, Northern Border University, \\ Rafha 76312, Saudi Arabia; fahdah.ayed@nbu.edu.sa \\ 8 Department of Animal Nutrition, University of Agriculture, Peshawar 25000, Pakistan; \\ mobashar@aup.edu.pk \\ 9 Department of Chemistry, College of Science, King Khalid University, Abha 9004, Saudi Arabia; \\ mhadam@kku.edu.sa \\ 10 Central Laboratory for Agricultural Climate, Agricultural Research Centre, Ministry of Agriculture and \\ Land Reclamation, Dokki-Giza 12311,Egypt; mohamed.o.taqi@gmail.com \\ 11 Regional Centre for Food and Feed (RCFF), Agricultural Research Centre, 12619 Cairo, Egypt; \\ elgafary1987@gmail.com \\ 12 Department of Physics, Faculty of Science, South Valley University, Qena 83523, Egypt; \\ mahmoud.abdelsadek@sci.svu.edu.eg \\ 13 Department of Nutrition and Clinical Nutrition, Faculty of Veterinary Medicine, Zagazig University, \\ Zagazig 44511, Egypt; drabdalla75@yahoo.com \\ 14 Department of Theriogenology, Faculty of Veterinary Medicine, South Valley University, Qena 83523, Egypt \\ * Correspondence: aabdelrahman@kku.edu.sa or ahmed.ezzat@vet.svu.edu.eg; Tel.: +966-0583414564
}

Received: 10 November 2020; Accepted: 20 November 2020; Published: 27 November 2020 updates

Simple Summary: The present study aimed to investigate the beneficial effects of supplementing zinc oxide nanoparticles (ZnO-NPs), thyme oil (THO), or their combination on the reproductive parameters, nutrient digestibility coefficients, and some blood metabolites of male Californian rabbits. Results showed an improvement in the nutrients digestibility, liver and kidney functions, testosterone concentration, and semen characteristics (semen volume, sperm motility, vitality, and morphology). ZnO-NPs were more effective in improving the male fertility, while THO showed a marked improvement in nutrient digestibility. Therefore, the inclusion of ZnO-NPs, or THO, or both is recommended for a rabbit feeding regimen to improve the feeding profitability.

Abstract: The present study aimed to determine the effects of zinc oxide nanoparticles (ZnO-NPs), thyme oil (THO), or their combination on the nutrient digestibility coefficients, reproductive 
parameters, and some blood metabolites of male Californian rabbits. One hundred rabbits, 29-weeks of age (initial body weight $3.48 \pm 0.08 \mathrm{~kg}$ ) were randomly distributed into four groups, 25 rabbits each. Treatment groups were fed a control diet, a control diet supplemented with ZnO-NPs $(100 \mathrm{mg} / \mathrm{kg})$, THO (500 mg/kg), or combination of ZnO-NPs (100 mg/kg) and THO (500 mg/kg). The feeding trial lasted for 35 days. Results showed improvements in dry matter, crude protein, ether extract, and crude fiber in $\mathrm{ZnO}-\mathrm{NPs}$, THO, and their combination treated groups compared to those of control. Furthermore, semen volume, sperm motility, vitality, and morphology were significantly improved $(p<0.01)$ in ZnO-NPs and THO groups rather than the control. Both ZnO-NPs and THO, as either individual or combined treatments significantly improved the serum alanine amino-transferase (ALT), aspartate amino-transferase (AST), urea, and creatinine compared to the control. Moreover, serum concentrations of testosterone were significantly increased in rabbits supplemented with $\mathrm{ZnO}-\mathrm{NPs}$, THO, or their combination compared to those of control $(p<0.05)$. In conclusion, ZnO-NPs, THO, or their combination improved the digestibility of nutrients, liver/ kidney functions, semen characteristics, and testosterone concentration in male rabbits.

Keywords: nano-zinc; nutrient digestibility; thyme oil; semen characteristics; testosterone

\section{Introduction}

Feed additives of trace minerals in nanoparticles were recently used to improve the productive and reproductive parameters of farm animals [1,2]. The nano-scaled size particles, e.g., nano zinc-oxide (ZnO-NPs; 1-100 nm), provided novel physical, chemical, and biological properties [3,4]. Zinc plays a pivotal role in the sperm cell functions, including lipid flexibility, cell membrane stabilization [5], sperm capacitation, and acrosomal reaction [6]. Moreover, it was found to increase the semen volume, total live sperm count, sperm motility and conception in heat-stressed rabbits [7], while its deficiency exerted oxidative damages, infertility, and worse sperm quality due to impaired spermatogenesis, lowered testosterone secretion, and increased sperm abnormalities [8]. Zinc supplementation was used to improve the sperm count, motility, form, function, quality, and fertilizing capacity [1]. The commonly used grains in rabbit diets are rich in phytate that may reduce or inhibit absorption of zinc $[9,10]$.

Thyme (Thymus vulgaris L.) improves the growth rate, antioxidant activity, and appetite promotion [11-16]. Likewise, supplementation with thyme oil (THO; $0.5 \mathrm{~g} / \mathrm{kg}$ ) was found to improve the intestinal integrity and total antioxidant status of rabbits [17]. The main components of thyme oil are thymol, carvacrol, p-cymene, g-terpinene, linalool, b-myrcene, and terpinen-4-ol [13,18]. Those constituents were known to have antioxidant properties [19] and may improve liver and kidney functions and abdominal fat accumulation [13,20].

The present study investigates the effects of zinc in nanoparticle form and thyme essential oils for improving the reproductive parameters, nutrient digestibility coefficients, and some blood metabolites of the male Californian rabbits.

\section{Materials and Methods}

\subsection{Experimental Animals, Design and Management}

The study was conducted at the rabbit research farm, Department of Animal and Poultry Production, Faculty of Agriculture, South Valley University, Qena, Egypt. A completely randomized design was used for investigating effects of ZnO-NPs, THO and their combination. A total of 100 of 29-weeks-old male Californian rabbits (initial body weight $3.48 \pm 0.08 \mathrm{~kg}$ ) were randomly distributed into four equal groups $(n=25)$. Treatment groups were fed a control diet, a control diet supplemented with ZnO-NPs $(100 \mathrm{mg} / \mathrm{kg})$, THO (500 mg/kg), or a combination of ZnO-NPs $(100 \mathrm{mg} / \mathrm{kg})$ and THO $(500 \mathrm{mg} / \mathrm{kg})$. The treatments were continuing for 35 days. Animals were individually reared in a 
closed building in cages (measuring $48 \mathrm{~cm} \times 55 \mathrm{~cm} \times 38 \mathrm{~cm}$, for width $\times$ length $\times$ height, respectively) of galvanized wire net, equipped with an automatic drinkers and manual feeders. Ambient temperature was maintained at $22{ }^{\circ} \mathrm{C}$ with a 12 -h light/dark cycle. The feed and fresh tap water was available ad libitum. The basal diet and its feeding value were presented in Table 1. Rabbits were managed for the experiment according to the animal rights and ethical committee in South Valley University, Egypt. The experiment protocol (SVUAGR.42018) was approved by the Animal Ethics Committee of Animal and Poultry Department, South Valley University in accordance with the guidelines of Egyptian Research Ethics Committee and the guidelines contained in the Guide for the Care and Use of Laboratory Animals (2011).

Table 1. Ingredient and chemical composition (as-fed basis) of the control diet fed to rabbits throughout the experimental periods.

\begin{tabular}{cccc}
\hline Ingredients & $\%$ & Chemical Analysis & $\%$ \\
\hline Yellow maize grain & 32.00 & Dry matter & 91.40 \\
Wheat bran & 20.00 & Ash & 9.80 \\
Soybean meal $(44 \% \mathrm{CP})$ & 18.00 & Crude protein & 17.00 \\
Wheat straw & 12.00 & Crude fiber & 12.60 \\
Lucerne hay & 5.00 & Ether extract & 2.90 \\
Rice bran & 5.00 & Digestible energy (MJ/kg) & 9.42 \\
Linseed straw & 2.80 & Calcium & 1.30 \\
Sunflower meal & 2.50 & Phosphorus & 0.86 \\
Lime stone & 2.00 & Lysine & 0.60 \\
Sodium chloride & 0.30 & Methionine & 0.41 \\
Vitamin-mineral premix & 0.30 & & \\
dl-Methionine & 0.10 & & \\
Zinc & 0.09 & & \\
\hline
\end{tabular}

${ }^{1}$ Per kg of ration: vitamin A $10.000 \mathrm{IU}$, vitamin $\mathrm{D}_{3} 900 \mathrm{IU}$, vitamin E $50.0 \mathrm{mg}$, vitamin K $2.0 \mathrm{mg}$, vitamin $\mathrm{B}_{1} 2.0 \mathrm{mg}$, folic acid $5.0 \mathrm{mg}$, pantothenic acid $20.0 \mathrm{mg}$, vitamin $\mathrm{B}_{6} 2.0 \mathrm{mg}$, choline $1200 \mathrm{mg}$, vitamin $\mathrm{B}_{12} 0.01 \mathrm{mg}$, niacin $50 \mathrm{mg}$, biotin $0.2 \mathrm{mg}$, Cu $0.1 \mathrm{mg}$, Fe $75.0 \mathrm{mg}, \mathrm{Mn} 8.5 \mathrm{mg}, \mathrm{Zn} 70 \mathrm{mg}$.

\subsection{Zinc Oxide Nanoparticles and Thyme Oil Preparation}

Zinc oxide nanoparticles (Cas no.1314-13-2, Sigma-Aldrich, Steinheim, Germany) concentration was $20 \mathrm{wt} . \%$ in distillated water, and their size is less than $40 \mathrm{~nm}$. Using dynamic light scattering technique, the particle hydrodynamic diameter was less than $100 \mathrm{~nm}$. The pH was $7.5 \pm 1.5$ (for aqueous systems) and density was $1.7 \pm 0.1 \mathrm{~g} / \mathrm{mL} 60.1 \mathrm{~g} / \mathrm{mL}$ at $25{ }^{\circ} \mathrm{C}$ [21]. The structural morphology of the particle was performed through scanning and transmission electron microscope (SEM, TEM) (Figure 1). The chemical compounds of the hydrodistilled THO (Table 2) was analyzed through a gas chromatography-spectrometry (GC-MS; Sigma 300 apparatus attached to a HP of 5970 300 mass spectrometer) system. Thyme essential oils (TEO) were analyzed by gas chromatography (Delsi 121C gas chromatograph) according to Abozid and Asker [22] (Table 2, Figure 2).
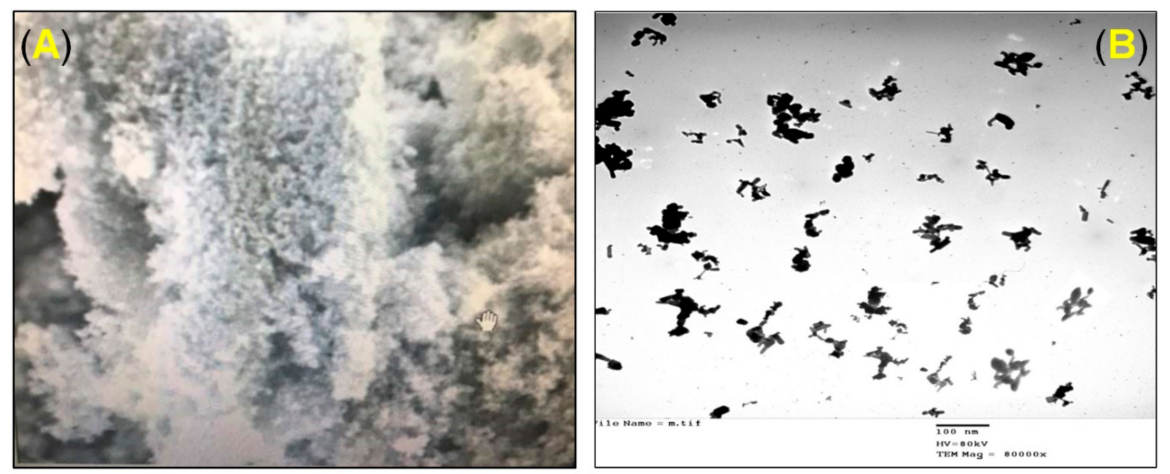

Figure 1. Scanning (SEM) (A), and transmission electron micrographs (TEM) (B) of synthesized zinc oxide nanoparticles (ZnO-NPs); $1-100 \mathrm{~nm}, \mathrm{HV}=80 \mathrm{kV}$, and TEM Mag = 8000×. 
Table 2. Major chemical compounds of hydrodistilled thyme essential oil (THO) as detected by gas chromatography spectrophotometer (GC-MS).

\begin{tabular}{|c|c|c|c|c|}
\hline Chemical Compounds & Rt. & Area \% & Mol. Weight (g/mol) & Chemical Formula \\
\hline p-Cymene & 6.99 & 23.59 & 134.218 & $\mathrm{C}_{10} \mathrm{H}_{14}$ \\
\hline B-linalool & 9.61 & 0.74 & 154.25 & $\mathrm{C}_{10} \mathrm{H}_{18} \mathrm{O}$ \\
\hline Carvone (Carvacrol) & 15.70 & 9.80 & 150.22 & $\mathrm{C}_{10} \mathrm{H}_{14} \mathrm{O}$ \\
\hline Anethole & 17.49 & 2.50 & 148.2 & $\mathrm{C}_{10} \mathrm{H}_{12} \mathrm{O}$ \\
\hline Thymol & 17.70 & 39.45 & 150.22 & $\mathrm{C}_{10} \mathrm{H}_{14} \mathrm{O}$ \\
\hline Carvacrol & 18.09 & 2.07 & 150.217 & $\mathrm{C}_{10} \mathrm{H}_{14} \mathrm{O}$ \\
\hline trans-Caryophyllene & 22.46 & 0.98 & 204.36 & $\mathrm{C}_{15} \mathrm{H}_{24}$ \\
\hline$\gamma$-terpinene & 25.14 & 12.49 & 136.23 & $\mathrm{C}_{10} \mathrm{H}_{16}$ \\
\hline Aromadenrene & 34.84 & 2.12 & 204.35 & $\mathrm{C}_{15} \mathrm{H}_{24}$ \\
\hline Ledol & 48.66 & 2.24 & 222.358 & $\mathrm{C}_{15} \mathrm{H}_{26}$ \\
\hline
\end{tabular}

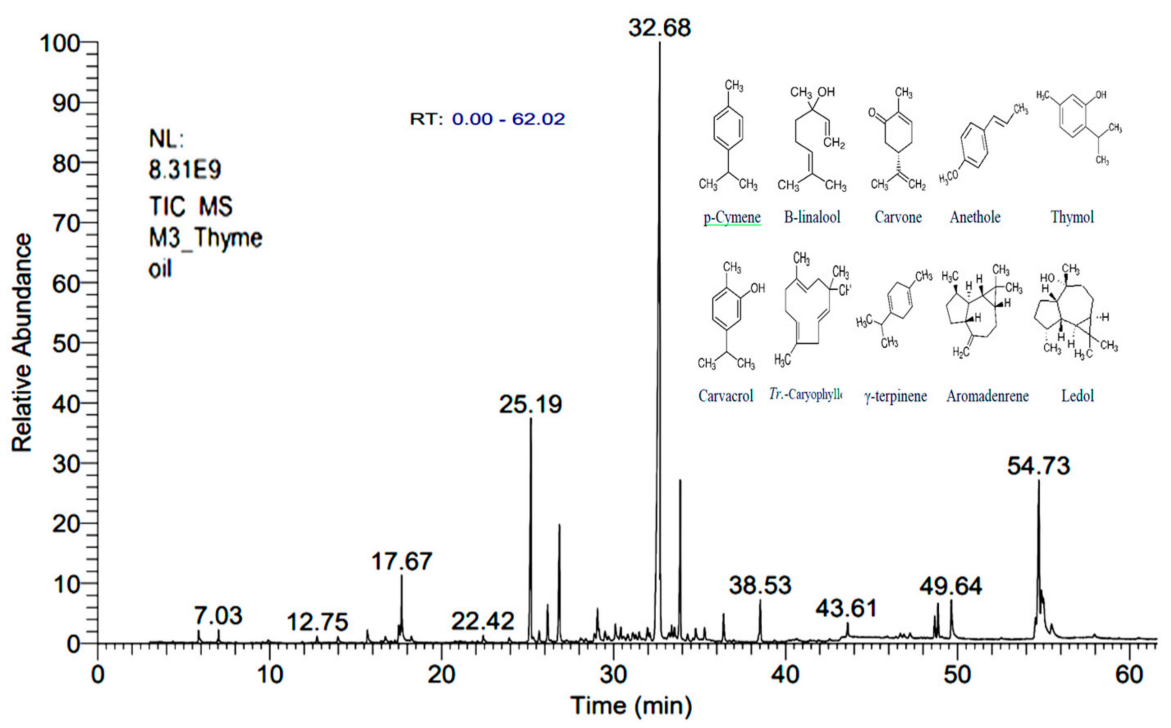

Figure 2. Retention time, area percent (\%) and formulae of the major chemical compounds of essential oils of thyme as detected by the gas chromatography-mass spectrometry (GC-MS).

\subsection{Nutrients Digestibility Trial}

At the end of the experiment at 33 weeks of age, a digestibility trial was carried out for four days. During the 4-day period trial, daily feed intake was determined and total faeces from each replicate were collected, weighed, and frozen at $-10^{\circ} \mathrm{C}$ until preparation for chemical analysis. Faecal samples were partially dried at $60^{\circ} \mathrm{C}$ for $48 \mathrm{~h}$ before being analyzed. Samples of the feed and faeces were analyzed for moisture by oven drying (930.15), ash by incineration (942.05), protein by Kjeldahl (984.13), and ether extract by Soxhlet fat analysis (954.02), calcium (927.02) and phosphorous (935.59) as described by the AOAC International (2006). Gross energy was determined using adiabatic bomb calorimetry (Parr Instrument Company, IL, USA). The digestibility of nutrients was calculated according to the following equation: Digestibility, $\%=[(\mathrm{t}-\mathrm{f}) / \mathrm{t}] \times 100$, where $t$ is the nutrient intake during the collection period $[\mathrm{g}]$ and $f$ is the amount of nutrient excreted in faeces $[\mathrm{g}]$. At the end of the experiment at 33 weeks of age, a digestibility trial was carried out for four days according to Perez et al. [23]. The DE refers to GE intake minus energy lost in faeces according to Hall et al. [24].

\subsection{Semen Collection and Evaluation}

Quality of semen ejaculates of the male rabbits was assessed as described by El-Desoky et al. [25]. The ejaculates were collected by using artificial vagina, in graduated collection tubes after removal of the gel mass. Semen was collected from 25 animals (one ejaculate from each animal and per treatment at 34 weeks of age. Assessments of live, dead, and abnormal sperms were performed by counting 200 sperm cells using an Eosin-Nigrosin staining mixture. Complete or partial purple- stained sperm cells were considered non-viable, whereas non-stained sperm cells were considered viable. Percentages 
of motile sperms at the warm stage showing progressive forward movement were visually calculated in several microscopic fields under $100 \times$ magnifications using light microscope.

\subsection{Blood Biochemical Assay}

At the end of the experimental period, the treated animals were anaesthetized by intramuscular injection of ketamine and xylazine, and then $5 \mathrm{~mL}$ blood was withdrawn from one of the marginal ear veins. Blood samples were centrifuged at $1008 \times g$ for $15 \mathrm{~min}$, where the serum was collected and stored at $-20^{\circ} \mathrm{C}$ until assayed for biochemical analysis. Serum testosterone concentrations were measured by immunoassay using commercial kits (Monobind Inc., Lake Forest, CA, USA). Liver enzymes; alanine transaminase (ALT) and aspartate transaminase (AST), as well as the kidney function markers; Creatinine and urea, concentrations were also measured by using standard diagnostic kits (Monobind Inc. Lake Forest, CA, USA).

\subsection{Statistical Analysis}

All data were analyzed using one-way analysis of variance (ANOVA) by using GraphPad Prism Software Version 3 (GraphPad Prism, San Diego, CA, USA). The significant differences between the treatments were confirmed by Tukey as a post-hoc test and distinguished by Duncan's multiple range [26] as letters on bars $(a, b, c)$. All values were expressed as mean \pm SEM for 25 animals. The differences between groups were considered significant at $p<0.05$.

\section{Results}

\subsection{Nutrient Digestibility Coefficients}

Effects of dietary nano-zinc oxide (ZnO-NPs), thyme oil (THO), or their combination; $\mathrm{ZnO}-\mathrm{NPs}+\mathrm{THO}$, on nutrients digestibility coefficients were shown in Table 3. All treatments, $\mathrm{ZnO}-\mathrm{NPs}, \mathrm{THO}$, and $\mathrm{ZnO}-\mathrm{NPs}+\mathrm{THO}$, significantly increased the nutrients' digestibility compared to each respective control; dry matter ( $68.38 \pm 0.71$ vs. $64.70 \pm 1.02 \%)$, crude protein ( $85.56 \pm 0.51$ vs. 78.06 $\pm 1.13 \%)$, Ether extract $(88.40 \pm 1.46$ vs. $80.98 \pm 0.89 \%)$, and crude fiber $(27.91 \pm 0.61$ vs. $24.92 \pm 1.67 \%)$ $(p<0.05)$.

Table 3. Effect of nanoparticles-zinc oxide (ZnO-NPs; $100 \mathrm{mg} / \mathrm{kg}$ ), thyme oil (THO; $500 \mathrm{mg} / \mathrm{kg}$ ) and their combination (ZnO-NPs; $100 \mathrm{mg} / \mathrm{kg}+$ THO $500 \mathrm{mg} / \mathrm{kg}$ ) on nutrient digestibility of male rabbits. Letters $(a, b, c)$ denote the significant differences between the groups.

\begin{tabular}{cccccc}
\hline \multirow{2}{*}{ Items } & \multicolumn{5}{c}{ Nutrient Digestibility\% } \\
\cline { 2 - 5 } & \multicolumn{4}{c}{ Treatments (Mean \pm SEM) } & \multirow{2}{*}{-Value } \\
\cline { 2 - 5 } & Control & ZnO-NPs & THO & ZnO-NPs + THO \\
\hline Feed inatke g/day & $155 \pm 2.01$ & $157 \pm 2.11$ & $158 \pm 2.21$ & $159 \pm 2.05$ & 0.089 \\
Dry matter & $64.70 \pm 1.02^{\mathrm{b}}$ & $67.32 \pm 1.03^{\mathrm{a}}$ & $68.38 \pm 0.71^{\mathrm{a}}$ & $67.04 \pm 0.69^{\mathrm{a}}$ & 0.001 \\
Crude protein & $78.06 \pm 1.13^{\mathrm{b}}$ & $84.30 \pm 1.06^{\mathrm{a}}$ & $85.56 \pm 0.51^{\mathrm{a}}$ & $84.30 \pm 1.33^{\mathrm{a}}$ & 0.001 \\
Ether extract & $80.98 \pm 0.89^{\mathrm{b}}$ & $87.24 \pm 1.55^{\mathrm{a}}$ & $88.40 \pm 1.46^{\mathrm{a}}$ & $86.98 \pm 0.58^{\mathrm{a}}$ & 0.040 \\
Crude fiber & $24.92 \pm 1.67^{\mathrm{b}}$ & $27.40 \pm 1.02^{\mathrm{a}}$ & $27.91 \pm 0.61^{\mathrm{a}}$ & $27.05 \pm 1.22^{\mathrm{a}}$ & 0.035 \\
Energy & $66.71 \pm 1.30^{\mathrm{b}}$ & $67.90 \pm 1.34^{\mathrm{a}}$ & $69.52 \pm 1.42^{\mathrm{a}}$ & $68.24 \pm 1.23^{\mathrm{a}}$ & 0.031 \\
\hline
\end{tabular}

${ }^{a-c}$ Means not sharing a common superscript in a row are significantly different $(p<0.05)$. Means are average of twenty replicates ( $n=25$ animals per treatment) determined at the end of the experimental period. ZnO-NPs: Nanoparticles of zinc oxide THO: Thyme oil; ZnO-NPs + THO: combination of nanoparticles of zinc oxide and thyme oil; SEM: Standard error of the mean.

\subsection{Semen Quality}

Supplementation of ZnO-NPs, THO or ZnO-NPs + THO effects on fertility in terms of semen volume, sperm motility, vitality, and morphology of the male rabbits were shown in Table 4. All treatments significantly improved the semen quality compared to that of control, like; increased 
sperm vitality, motility, and semen volume in variable potencies $(p<0.001)$. Abnormal sperm cells in response to all treatments were significantly lowered compared to those of control $(p<0.001)$. The $\mathrm{ZnO}-\mathrm{NPs}$ were the best in decreasing the sperm shape abnormality $(15.58 \pm 0.51 \%)$, while THO could be the best stimulating factor of sperm motility $(75.67 \pm 0.86 \%)$. Although, no significant differences were detected between the treated groups, the combined treatment of ZnO-NPs and THO tended to be the most effective factor in increasing the sperm vitality $(84.50 \pm 0.70 \%)$. The ZnO-NPs or THO significantly increased the volume of semenal plasma compared to the controls $(p<0.05)$, while the combined $\mathrm{ZnO}-\mathrm{NPs}+\mathrm{THO}$ highly increased the volume of semen compared to controls $(p<0.0001)$ rather than either $\mathrm{ZnO}-\mathrm{NPs}$ or/ THO each alone $(p<0.05)$.

Table 4. Effect of $\mathrm{ZnO}-\mathrm{NPs}$, THO and their combination on semen characteristic of male Californian rabbits.

\begin{tabular}{|c|c|c|c|c|c|}
\hline \multirow{2}{*}{ Items } & \multicolumn{4}{|c|}{ Treatments (Mean \pm SEM) } & \multirow{2}{*}{$p$-Value } \\
\hline & Control & ZnO-NPs & THO & ZnO-NPs + THO & \\
\hline Live sperm \% & $77.34 \pm 0.68^{b}$ & $83.99 \pm 0.84^{a}$ & $84.20 \pm 0.59^{a}$ & $84.50 \pm 0.70^{a}$ & 0.003 \\
\hline Abnormal sperm $\%$ & $17.40 \pm 0.41^{a}$ & $15.58 \pm 0.51^{b}$ & $15.10 \pm 0.50^{b}$ & $15.20 \pm 0.37^{b}$ & 0.001 \\
\hline Sperm motility \% & $56.67 \pm 1.51^{b}$ & $75.00 \pm 1.49^{a}$ & $75.67 \pm 0.86^{\mathrm{a}}$ & $73.33 \pm 0.68^{a}$ & 0.002 \\
\hline Semen volume, $\mathrm{ml}$ & $0.63 \pm 0.01^{\mathrm{c}}$ & $0.74 \pm 0.01^{b}$ & $0.72 \pm 0.02^{b}$ & $0.76 \pm 0.01^{\mathrm{a}}$ & $<0.05-0.0001$ \\
\hline
\end{tabular}

$\overline{\mathrm{a}-\mathrm{c}}$ Means not sharing a common superscript in a row are significantly different $(p<0.05)$. Means are average of twenty replicates ( $n=25$ animals per treatment) determined at the end of the experimental period. ZnO-NPs: Nanoparticles of zinc oxide THO: Thyme oil; ZnO-NPs + THO: combination of nanoparticles of zinc oxide and thyme oil; SEM: Standard error of the mean.

\subsection{Serobiochemical Assays}

Effects of $\mathrm{ZnO}-\mathrm{NPs}$, THO, or their combination on the liver and kidney function markers as well as testosterone levels in serum of the tested rabbits are shown in Figures 3-5, respectively. Rabbits received either $\mathrm{ZnO}-\mathrm{NPs}$, THO, or their combination; $\mathrm{ZnO}-\mathrm{NPs}+\mathrm{THO}$ showed the lower serum levels of ALT $(17.4 \pm 0.06,17.0 \pm 0.51,16.8 \pm 0.50 \mathrm{IU} / \mathrm{L}$, respectively) compared to control $(23.2 \pm 0.50 \mathrm{IU} / \mathrm{L})(p<0.0001)$ (Figure 3A). The serum concentrations of AST in response to ZnO-NPs, $\mathrm{THO}$, or ZnO-NPs + THO were also significantly decreased $(17.8 \pm 0.40,17.1 \pm 0.5,16.9 \pm 0.80 \mathrm{IU} / \mathrm{L}$, respectively) compared to control $(26.3 \pm 0.3 \mathrm{IU} / \mathrm{L})(p<0.0001)$ (Figure 3B).

(A)

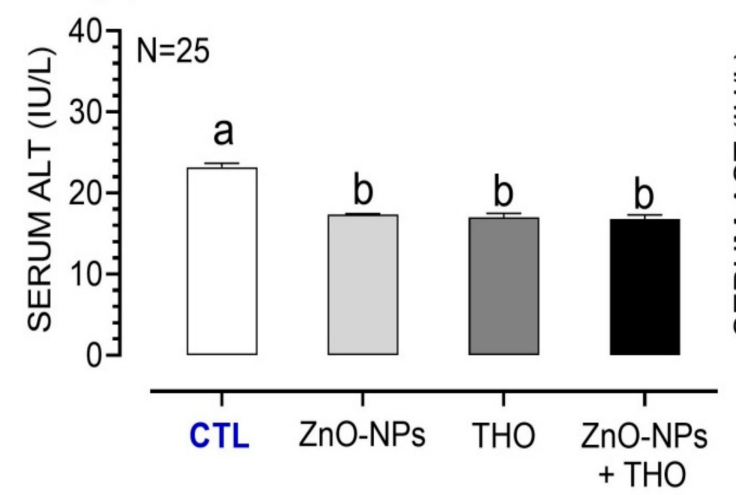

(B)

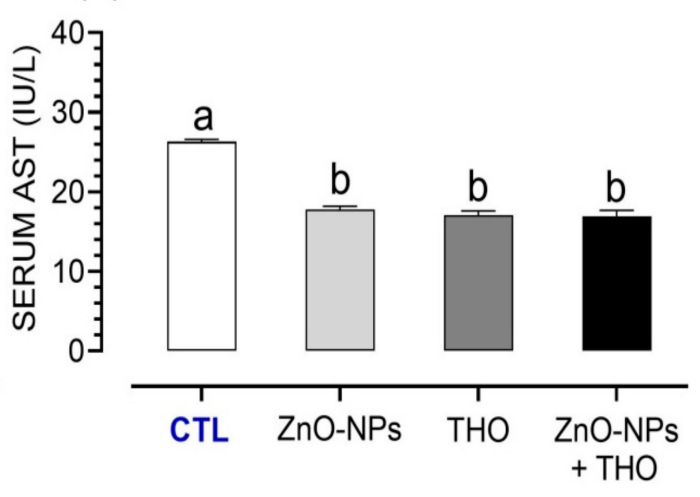

Figure 3. Serum concentrations of liver markers; alanine amino transferase (ALT) (A) and aspartate amino transferase (AST) (B) in response to supplementation of ZnO-NPs, THO, combined doses of both ZnO-NPs + THO, or a control (CTL) in male Californian rabbits. Letters on the bars a, b denote the significant difference between the different treatments $(p<0.05)$. 
(A)

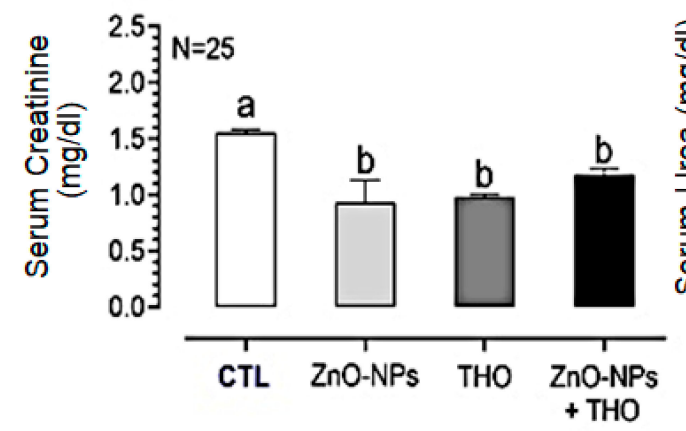

(B)

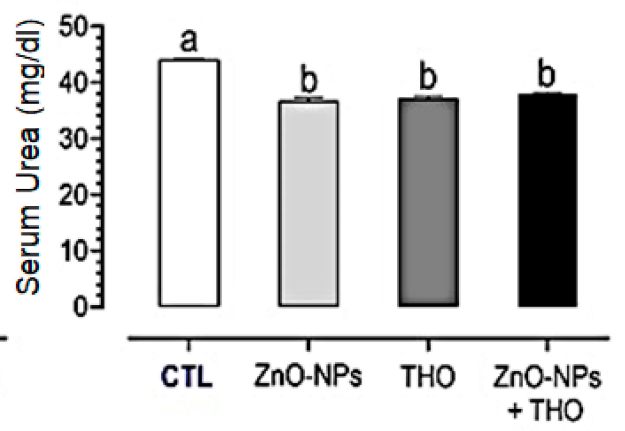

Figure 4. Serum concentrations of creatinine $(\mathrm{Cr})(\mathrm{A})$ and urea $(\mathbf{B})$ in response to supplementation of ZnO-NPs, THO, ZnO-NPs + THO, or a control (CTL) in male Californian rabbits, respectively. Other explanations were given in Figure 3.
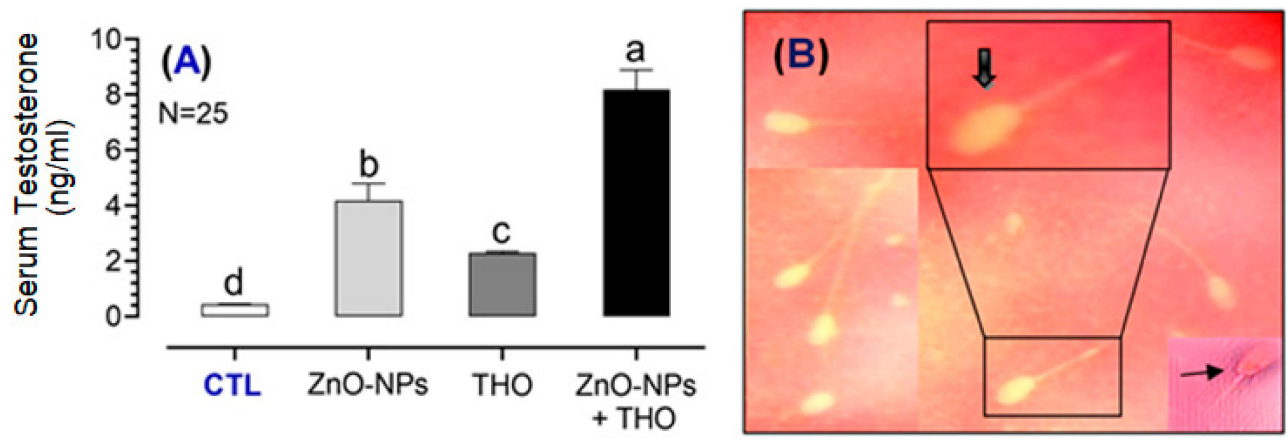

Figure 5. Serum concentrations of testosterone in response to supplementation with ZnO-NPs, $\mathrm{THO}$, or ZnO-NPs + THO vs. control (CTL), respectively, is shown in (A). All treated groups significantly increased the testosterone concentrations with variable potencies, compared to control. Also, the combined treatment; ZnO-NPs was the most potent stimulator. Letters on bars (a, b, c, d) denote the significant differences between groups at $p<0.05$. Alive, non-stained white (Thick arrow), and dead, red-stained sperm cell (thin arrow) are shown in (B). The red eosin stain could not penetrate the living sperm cells which appear white, but those dead spermatozoa are stained red with eosin, and so the sperm vitality could be distinguished and calculated.

Likewise, serum creatinine and urea were significantly decreased in response to ZnO-NPs, $\mathrm{THO}$, or; $\mathrm{ZnO}-\mathrm{NPs}+\mathrm{THO}$ compared to the controls $(p<0.0001)$ (Figure 4$)$. The serum concentrations of creatinine $(\mathrm{Cr})$ in response to $\mathrm{ZnO}-\mathrm{NPs}$, THO, or $\mathrm{ZnO}-\mathrm{NPs}+\mathrm{THO}$ were significantly decreased $(0.93 \pm 0.20,0.98 \pm 0.02,1.18 \pm 0.05 \mathrm{mg} / \mathrm{dl}$, respectively) compared to control $(1.55 \pm 0.03 \mathrm{mg} / \mathrm{dl})$ $(p<0.0001)$ (Figure 4A). Furthermore, the serum concentrations of urea in response to ZnO-NPs, $\mathrm{THO}$, or ZnO-NPs $+\mathrm{THO}$ were significantly decreased $(36.7 \pm 0.60,37.2 \pm 0.40,38.0 \pm 0.20 \mathrm{mg} / \mathrm{dl}$, respectively) rather than those of controls $(44.1 \pm 0.10 \mathrm{mg} / \mathrm{dl})(p<0.0001)$ (Figure $4 \mathrm{~B})$.

All treatments, $\mathrm{ZnO}-\mathrm{NPs}$, THO, or the combined $\mathrm{ZnO}-\mathrm{NPs}+\mathrm{THO}$, significantly increased the serum concentrations of testosterone (T) $(4.2 \pm 0.60,2.3 \pm 0.05,8.20 \pm 0.70 \mathrm{ng} / \mathrm{mL}$, respectively) compared to control $(0.45 \pm 0.01 \mathrm{ng} / \mathrm{mL})$ in variant potencies $(p<0.05-0.0001)$. However, the combined $\mathrm{ZnO}-\mathrm{NPs}+\mathrm{THO}$ treatment was the most effective rather than the CTL or the other treatment groups; ZnO-NPs or THO (Figure 5A). Sperm cells of the tested rabbits were stained with eosin-nigrosin showing unstained alive cells and those red-stained dead (Figure 5B).

\section{Discussion}

Dietary essential oils are digestive enhancers with specific antimicrobial activity which promotes the general health condition [14,27]. Thyme oil (THO) accordingly showed a beneficial effect on the rabbit performance, welfare, and health status especially in hot environments $[13,17,28]$. It was reported 
that thyme oil plays a pivotal role in stimulating the feed intake, increasing the body weight/gain and intestinal integrity, and thus improving the overall feed conversion ratio $[13,17]$. Those positive effects were attributed to the thyme compounds on the digestive efficiency [29]. Furthermore, zinc oxides in the form of nanostructure have become interesting areas of research in animal husbandry [30]. Due to scarcity of available reports on effect of zinc oxide nanoparticles on the male of rabbits, comparison was done with other studies that used other zinc sources. Nanoparticles exhibit novel properties, such as great specific surface area, high surface activity with high catalytic efficiency [31]. The mineral nanoparticles can increase absorption [32,33]. Zinc requirement for rabbits is $30-170 \mathrm{mg} / \mathrm{kg}$ dry matter, with higher requirements for breeders [34,35]. Zinc plays a pivotal role in carbohydrates, lipids and protein metabolism for energy utilization liberated from feeds digestion [36,37]. The mineral is approved as essential cofactor for the metabolic reactions and enzyme activity especially the carrier proteins regulating digestion [38]. It was found that higher proportion of $\mathrm{Zn}(170 \mathrm{mg} / \mathrm{kg})$ had improved the nutrient digestibility of rabbits compared to non-treated control group [35]. Simultaneously, in this study, the nanoparticles of zinc oxide (ZnO-NPs; $100 \mathrm{mg} / \mathrm{kg} \mathrm{BW),} \mathrm{thyme} \mathrm{oil} \mathrm{(THO;} 500 \mathrm{mg} / \mathrm{kg} \mathrm{BW),}$ or their combination significantly increased the dry matter, crude protein, ether extract, and crude fiber digestibility compared to each respective control group that could be attributed to improvement of enzymes' activities induced by zinc [39-42] in addition to the improved digestibility induced by thyme [43] as stated in other species.

Chandak et al. [44] found that THO has a synergistic effect with zinc oxide and showed higher levels of antimicrobial effect against the root canal pathogens. In present study, rabbits received either ZnO-NPs, THO, or their combination significantly lowered the serum levels of ALT, AST, urea, and creatinine when compared to the control group $(p<0.001)$. Furthermore, concentrations of testosterone in the serum increased significantly in those male rabbits received with ZnO-NPs, THO, or their combination when compared to the control $(p<0.05)$. Improvement in liver and kidney functions as well as that the male sex steroid, testosterone, is attributed to the role of $\mathrm{Zn}$ in many biochemical processes and physiological functions. It has been reported that $\mathrm{Zn}$ is required for the normal function of plentiful structural proteins, enzymes, and hormones which are necessary for growth and development [45]. The improved concentrations of testosterone in response to Zn-diets supplemented groups might be due to enhancing the Leydig cells of the testis for increasing the levels of testosterone production [7,46,47]. A combination of ZnO-NPs and THO improved liver and kidney function as well as serum testosterone of Californian male rabbits indicating a possible synergistic effect of $\mathrm{ZnO}-\mathrm{NPs}$ and THO in improving testosterone secretion. The study showed that supplementation of the ZnO-NPs, THO, or their combination to rabbits exhibited a significant increase in the ejaculate volume, sperm viability, and sperm motility. No information is available regarding the effect of nano zinc oxide supplementation on semen quality and fertility of male rabbit. However, our results were consistent with Moce et al. [48] who stated increased numbers of spermatozoa of rabbit bucks fed on rations supplemented with zinc in amount of 35 to $100 \mathrm{mg} / \mathrm{kg}$, as compared to their control group. Supplementation of $\mathrm{Zn}$ in doses of 50, 100, and $150 \mathrm{mg} / \mathrm{kg}$ to rabbit diet increased spermatozoa concentration of male rabbits [49]. Zn plays a pivotal role in the production of spermatozoa in parallel to the synthesis of DNA and RNA by enhancing the activity of DNA and RNA polymerases [50]. Furthermore, Zn supplementation was reported to duplicate the blood concentration levels of testosterone in adult men [51].

Acconcia and Marino [52] have reported that all the mammalian steroids including testosterone are biosynthesized from cholesterol. Testosterone is anabolic agent especially for the skeletal muscles and brain, and the trace amount of testosterone is synthesized in the adrenal cortex, but the profound production comes from the interstitial testicular Leydig cells [52]. Effects of ZnO-NPs and/or THO on blood testosterone could reflect their effects on cholesterol or other cellular and biochemical factors. Previous studies in other animal species stated that thyme extract [20] or ZnO-NPs [53] significantly lowered the blood concentrations of cholesterol. Accordingly, the blood cholesterol could be directed for the production of testosterone in agreement with our findings. Moreover, Zn concentrations in the 
Leydig cells were found to be significantly lowered in mice fed a Zn-deficient diet compared to controls, and that the zinc transporter-7 (ZnT7) was principally expressed in the Leydig cells ZnT7 which plays an important role in the regulation of testosterone synthesis by modulating the steroidogenic enzymes [54]. All above suggests that zinc could play a direct pivotal role on those testosterone-secreting cells which coincide with our findings for the highest increment of testosterone in response to ZnO-NPs supplementation. The effect of thyme on the blood testosterone concentrations was studied in male rats showing significant increase of the hormone in response to $5 \%$ thyme-supplemented diet compared to control throughout 28 days [55]. Therefore, supporting our results, coadministration of ZnO-NPs and THO synergistically increase the testosterone concentration rather than each alone. Two pathways could explain our findings; (a) testosterone synthesis from cholesterol induced by THO [20], or (a) endogenous molecular factors in the Leydig cells stimulated by the ZnO-NPs which require additional research and molecular studies [54]. The same pathway explains the increased secretion and volume of seminal plasma from the accessory genital glands which mainly depend on the testosterone secretion [56]. Those findings suggest that either $\mathrm{ZnO}-\mathrm{NPs}$ or THO could stimulate the Leydig cells to secrete the synthesized testosterone, but the combined treatment, i.e., ZnO-NPs plus THO, may enhance both the synthesis and secretion of the hormone from its sources. Dietary supplementation with those additives compensate for the deficient nutrients required for male fertility and could resume the normal pathway of spermatogenesis, including the sperm cells morphology, vitality, and motility, in addition to stimulating the sex glands to produce much of the seminal plasma.

\section{Conclusions}

In view of the above findings, it can be concluded that $\mathrm{ZnO}-\mathrm{NPs}, \mathrm{THO}$, or their combination in rabbit feeding resulted in improved nutrient digestibility, liver and kidney functions, as well as semen quality. The combined treatment of ZnO-NPs with THO suggested a possible synergistic effect for stimulating testosterone secretion and increasing the volume of seminal plasma. Further molecular analysis and fertility studies are required to elaborate on this combinational effect.

Author Contributions: Conceptualization, A.A.A.A.-W. and A.E.A; methodology, M.A.A.-K.; software, K.M.A.; validation, I.M.S.; F.A.A., M.M. and F.M.S.; statistics, formal analysis and revision, M.H.A.S.; investigation, A.H.H.A. and A.A.A.A.-W.; resources, M.O.T.; data curation, H.G.M.E.-S.; writing-original draft preparation, A.A.A.A-W.; writing-review and editing, A.E.A. and A.E.M.; Materials preparation, M.S.A.E.-S.; data curation, A.E.M.; visualization, A.E.A. All authors have read and agreed to the published version of the manuscript.

Funding: Deanship of Scientific Research at King Khalid University, Grant/Award Number: Group Research Project (Number R.G.P.1/157/40).

Acknowledgments: The authors are thankful for the research funds from Deanship of Scientific Research at King Khalid University, Saudi Arabia and South Valley University, Egypt for supporting this project.

Conflicts of Interest: The authors declare that there are no conflict of interest.

\section{References}

1. Egwurugwu, J.N.; Ifedi, C.U.; Uchefuna, R.C.; Ezeokafor, E.N.; Alagwu, E.A. Effects of zinc on male sex hormones and semen quality in rats. Niger. J. Physiol. Sci. 2013, 28, 17-22.

2. Tsai, Y.H.; Mao, S.Y.; Li, M.Z.; Huang, J.T.; Lien, T.F. Effects of nanosize zinc oxide on zinc retention, eggshell quality, immune response and serum parameters of aged laying hens. Anim. Feed Sci. Technol. 2016, 213, 99-107. [CrossRef]

3. Wang, Z.L. Characterization of Nanophase Material; Wiley-VCH Verlag GmbH: Weinheim, Germany, $2000 ;$ p. 1.

4. Swain, P.S.; Rao, S.B.N.; Rajendran, D.; Dominic, G.; Selvaraju, S. Nano zinc, an alternative to conventional zinc as animal feed supplement: A review. Anim. Nutr. 2016, 2, 134-141. [CrossRef] [PubMed]

5. Chia, S.E.; Ong, C.N.; Chua, L.H.; Ho, L.M.; Tay, S.K. Comparison of zinc concentrations in blood and seminal plasma and the various sperm parameters between fertile and infertile men. J. Androl. 2000, 21, 53-57. [PubMed] 
6. Eggert-Kruse, W.; Zwick, E.M.; Batschulat, K.; Rohr, G.; Armbruster, F.P.; Petzoldt, D.; Strowitzki, T. Are zinc levels in seminal plasma associated with seminal leukocytes and other determinants of semen quality? Fertil. Steril. 2002, 77, 260-269. [CrossRef]

7. El-Masry, K.A.; Nasr, A.S.; Kamal, T.H. Influences of season and dietary supplementation with selenium and vitamin $\mathrm{E}$ or zinc on some blood constituents and semen quality of New-Zealand white rabbit males. World Rabbit Sci. 1994, 2, 79-86. [CrossRef]

8. Colagar, A.H.; Marzony, E.T.; Chaichi, M.J. Zinc levels in seminal plasma are associated with sperm quality in fertile and infertile men. Nutr. Res. 2009, 29, 82-88. [CrossRef] [PubMed]

9. Gibson, R.S.; Bailey, K.B.; Gibbs, M.; Ferguson, E.L. A review of phytate, iron, zinc, and calcium concentrations in plant-based complementary foods used in low-income countries and implications for bioavailability. Food Nutr. Bull. 2010, 31, S134-S146. [CrossRef]

10. McDowell, L.R. Minerals in Animal and Human Nutrition; Academy Press Inc: New York, NY, USA, 2003; pp. 265-292.

11. Abdel-Wareth, A.A.A.; Kehraus, S.; Hippenstiel, F.; Südekum, K.H. Effects of thyme and oregano on growth performance of broilers from 4 to 42 days of age and on microbial counts in crop, small intestine and caecum of 42-day-old broilers. Anim. Feed Sci. Technol. 2012, 178, 198-202. [CrossRef]

12. Abdel-Wareth, A.A.A.; Lohakare, J.D. Effect of dietary supplementation of peppermint on performance, egg quality, and serum metabolic profile of Hy-Line Brown hens during the late laying period. Anim. Feed Sci. Technol. 2014, 197, 114-120. [CrossRef]

13. Abdel-Wareth, A.A.A.; Taha, E.M.M.; Südekum, K.H.; Lohakare, J. Thyme oil inclusion levels in a rabbit ration: Evaluation of productive performance, carcass criteria and meat quality under hot environmental conditions. Anim. Nutr. 2018, 4, 410-416. [CrossRef] [PubMed]

14. Hippenstiel, F.; Abdel-Wareth, A.A.A.; Kehraus, S.; Südekum, K.H. Effects of selected herbs and essential oils, and their active components on feed intake and performance of broilers-A review. Arch. Geflïgelkd. 2011, 75, 226-234.

15. Alagawany, M.; Ashour, E.A.; Reda, F.M.; Abd El-Hac, M.E. Effect of Supplementation of Yucca schidigera Extract to Growing Rabbit Diets on Growth Performance, Carcass Characteristics, Serum Biochemistry and Liver Oxidative Status. Asian J. Anim. Vet. Adv. 2014, 9, 732-742. [CrossRef]

16. Rašković, A.; Pavlović, N.; Kvrgić, M.; Sudji, J.; Mitić, G.; Čapo, I.; Mikov, M. Effects of pharmaceutical formulations containing thyme on carbon tetrachloride-induced liver injury in rats. BMC Complement. Altern. Med. 2015, 15. [CrossRef] [PubMed]

17. Placha, I.; Chrastinova, L.; Laukova, A.; Cobanova, K.; Takacova, J.; Strompfova, V.; Chrenkova, M.; Formelova, Z.; Faix, S. Effect of thyme oil on small intestine integrity and antioxidant status, phagocytic activity and gastrointestinal microbiota in rabbits. Acta Vet. Hung. 2013, 61, 197-208. [CrossRef]

18. Lee, S.J.; Umano, K.; Shibamoto, T.; Lee, K.G. Identification of volatile components in basil (Ocimum basilicum L.) and thyme leaves (Thymus vulgaris L.) and their antioxidant properties. Food Chem. 2005, 91, 131-137. [CrossRef]

19. Rota, M.C.; Herrera, A.; Martínez, R.M.; Sotomayor, J.A.; Jordán, M.J. Antimicrobial activity and chemical composition of thymus vulgaris, thymus zygis and thymus hyemalis essential oils. Food Cont. 2008, 19, 681-687. [CrossRef]

20. Abdulkarimi, R.; Daneshyar, M.; Aghazadeh, A. Thyme (Thymus vulgaris) extract consumption darkens liver, lowers blood cholesterol, proportional liver and abdominal fat weights in broiler chickens. Ital. J. Anim. Sci. 2011, 10, e20. [CrossRef]

21. Cohen, J.; DeLoid, G.; Pyrgiotakis, G.; Demokritou, P. Interactions of engineered nanomaterials in physiological media and implications forin vitrodosimetry. Nanotoxicology 2012, 7, 417-431. [CrossRef]

22. Mostafa Abozid, M.; Asker, M.M.S. Chemical composition, antioxidant and antimicrobial activity of the essential oil of the thyme and rosemary. Int. J. Acad. Res. 2013, 5, 186-195. [CrossRef]

23. Perez, J.M.; Lbas, F.; Gidenne, T.; Martens, L.; Xicato, G.; Perigi-Bini, R.; Dallo-Zotte, A.; Cossu, M.E.; Carazzolo, A.; Villamide, M.J.; et al. European reference method for in vivo determination of diet digestibility. World Rabbit Sci. 1995, 3, 41-43.

24. Hall, J.A.; Melendez, L.D.; Jewell, D.E. Using gross energy improves metabolizable energy predictive equations for pet foods whereas undigested protein and fiber content predict stool quality. PLOS ONE 2013, 8, e54405. [CrossRef] 
25. El-Desoky, N.I.; Hashem, N.M.; Elkomy, A.; Abo-elezz, Z.R. Physiological response and semen quality of rabbit bucks supplemented with Moringa leaves ethanolic extract during summer season. Animal 2017, 11, 1549-1557. [CrossRef] [PubMed]

26. Duncan, D.B. Multiple Range and Multiple F Tests. Biometrics 1955, 11, 1. [CrossRef]

27. Bozkurt, M.; Hippenstiel, F.; Abdel-Wareth, A.A.A.; Kehraus, S.; Küçükyilmaz, K.; Südekum, K.H. Effects of selected herbs and essential oils on performance, egg quality and some metabolic activities in laying hense A review. Eur. Poult. Sci. 2014, 78, 15.

28. Attia, Y.A.; Bakhashwain, A.A.; Bertu, N.K. Thyme oil (Thyme vulgaris L.) as a natural growth promoter for broiler chickens reared under hot climate. Ital. J. Anim. Sci. 2017, 16, 275-282. [CrossRef]

29. Gerencser, Z.S.; Szendrő, Z.; Matics, Z.; Radnai, I.; Kovacs, M.; Nagy, I.; Cullere, M.; Dal Bosco, A.; Dalle Zotte, A. Effect of dietary supplementation of spirulina (Arthrospira platensis) and thyme (Thymus vulgaris) on apparent digestibility and productive performance of growing rabbits. World Rabbit Sci. 2014, 22, 1-9. [CrossRef]

30. Sangeetha, G.; Rajeshwari, S.; Venckatesh, R. Green synthesis of zinc oxide nanoparticles by aloe barbadensis miller leaf extract: Structure and optical properties. Mater. Res. Bull. 2011, 46, 2560-2566. [CrossRef]

31. Gao, X.; Matsui, H. Peptide-Based Nanotubes and Their Applications in Bionanotechnology. Adv. Mater. 2005, 17, 2037-2050. [CrossRef]

32. Yin Win, K.; Feng, S.S. Effects of particle size and surface coating on cellular uptake of polymeric nanoparticles for oral delivery of anticancer drugs. Biomaterials 2005, 26, 2713-2722. [CrossRef]

33. Liao, C.D.; Hung, W.L.; Jan, K.C.; Yeh, A.I.; Ho, C.T.; Hwang, L.S. Nano/sub-microsized lignan glycosides from sesame meal exhibit higher transport and absorption efficiency in Caco-2 cell monolayer. Food Chem. 2010, 119, 896-902. [CrossRef]

34. Mateos, G.G.; Blas, C. Minerals, vitamins and additives. In The Nutrition of the Rabbit; Blas, C., Wiseman, J., Eds.; CABI Publish: London, UK, 1998; Volume 9, pp. 145-175.

35. Chrastinová, L'.; Čobanová, K.; Chrenková, M.; Poláčiková, M.; Formelová, Z.; Lauková, A.; Ondruška, L'.; Simonová, P.M.; Strompfová, V.; Mlyneková, Z.; et al. Effect of dietary zinc supplementation on nutrients digestibility and fermentation characteristics of caecal content in physiological experiment with young rabbits. Slovak J. Anim. Sci. 2016, 49, 23-31.

36. Vallee, B.L.; Falchuk, K.H. The biochemical basis of zinc physiology. Physiol. Rev. 1993, 73, 79-118. [CrossRef] [PubMed]

37. MacDonald, R.S. The Role of Zinc in Growth and Cell Proliferation. J. Nutr. 2000, 130, 1500S-1508S. [CrossRef] [PubMed]

38. McCall, K.A.; Huang, C.-c.; Fierke, C.A. Function and Mechanism of Zinc Metalloenzymes. J. Nutr. 2000, 130, 1437S-1446S. [CrossRef] [PubMed]

39. Garg, A.K.; Mudgal, V.; Dass, R.S. Effect of organic zinc supplementation on growth, nutrient utilization and mineral profile in lambs. Anim. Feed Sci. Technol. 2008, 144, 82-96. [CrossRef]

40. Heo, J.M.; Kim, J.C.; Hansen, C.F.; Mullan, B.P.; Hampson, D.J.; Pluske, J.R. Effects of dietary protein level and zinc oxide supplementation on performance responses and gastrointestinal tract characteristics in weaner pigs challenged with an enterotoxigenic strain of Escherichia coli. Anim. Prod. Sci. 2010, 50, 827-836. [CrossRef]

41. Sarvari, B.G.; Seyedi, A.H.; Shahryar, H.A.; Sarikhan, M.; Ghavidel, S.Z. Effects of dietary zinc oxide and a blend of organic acids on broiler live performance, carcass traits, and serum parameters. Br. J. Poult. Sci. 2015, 17, 39-45. [CrossRef]

42. Mohammadi, V.; Ghazanfari, S.; Mohammadi-sangcheshmeh, A.; Nazaran, M.H. Comparative effects of zinc-nano complexes, zinc-sulphate and zinc-methionine on performance in broiler chickens. Br. Poult. Sci. 2015, 56, 486-493. [CrossRef]

43. Ribeiro, A.D.B.; Ferraz Junior, M.V.C.; Polizel, D.M.; Miszura1, A.A.; Barroso, J.P.R.; Cunha, A.R.; Souza, T.T.; Ferreira, E.M.; Susin, I.; Pires, A.V. Effect of thyme essential oil on rumen parameters, nutrient digestibility, and nitrogen balance in wethers fed high concentrate diets. Arq. Bras. Med. Vet. Zootec. 2020, 72, 573-580. [CrossRef]

44. Chandak, M.; Thosar, N.; Bhat, M.; Basak, S. Evaluation of antimicrobial activity of two endodontic sealers: Zinc oxide with thyme oil and zinc oxide eugenol against root canal microorganisms-An in vitro study. Int. J. Clin. Pediat. Dent. 2018, 11, 79-82. [CrossRef] [PubMed] 
45. Bao, Y.M.; Choct, M.; Iji, P.A.; Bruerton, K. Optimal dietary inclusion of organically complexed zinc for broiler chickens. Br. Poult. Sci. 2009, 50, 95-102. [CrossRef] [PubMed]

46. Fang, V.S.; Furuhashi, N. Partial Alleviation of the Antitesticular Effect of Pipecolinomethylhydroxyindane by Zinc in Rats. J. Endocrinol. 1978, 79, 151-152. [CrossRef] [PubMed]

47. Imam, S.; Ansari, M.R.; Kumar, R.; Mudga, V.; Varshney, V.P.; Dass, R.S. Effect of inorganic and organic zinc supplementation on serum testosterone level in murrah buffalo (Bubalus bubalis) bulls. Ind. J. Anim. Sci. 2009, $79,61$.

48. Moce, E.; Arouca, M.; Lavara, R.; Pascual, J.J. Effect of dietary zinc and vitamin supplementation on semen characteristics of high growth rate males during Summer season. In Proceedings of the 7th World Rabbit Congress, Valencia, Spain, 4-7 July 2000.

49. Oliveira, C.E.A.; Badu, C.A.; Ferreira, W.M.; Kamwa, E.B.; Lana, A.M.Q. Effects of dietary zinc supplementation on spermatic characteristics of rabbit breeders. In Proceedings of the 8th World Rabbit Congress, Puebla, Mexico, 7-10 September 2004; pp. 315-321.

50. Cheah, Y.; Yang, W. Functions of essential nutrition for high quality spermatogenesis. Adv. Biosci. Biotechnol. 2011, 2, 182-197. [CrossRef]

51. Prasad, A.S.; Mantzoros, C.S.; Beck, F.W.J.; Hess, J.W.; Brewer, G.J. Zinc status and serum testosterone levels of healthy adults. Nutrition 1996, 12, 344-348. [CrossRef]

52. Acconcia, F.; Marino, M. Steroid hormones: Synthesis, secretion, and transport. In Principles of Endocrinology and Hormone Action; Belfiore, A., LeRoith, D., Eds.; Endocrinology; Springer: Cham, Germany, 2017. [CrossRef]

53. Reza, E.H.; Kobra, S.; Leila, S.; Vahid, Y.B.; Esmaiel, A. Investigation of the zinc oxide nanoparticles effect on testosterone, cholesterol and cortisol in rats. Res. J. Recent Sci. 2014, 3, 14-19.

54. Chu, Q.; Chi, Z.; Zhang, X.; Liang, D.; Wang, X.; Zhao, Y.; Zhang, L.; Zhang, P. A potential role for zinc transporter 7 in testosterone synthesis in mouse Leydig tumor cells. Int. J. Mol. Med. 2016, 37, 1619-1626. [CrossRef]

55. Nashwa, A.H.A.; Nahed, M. El-M.; Rania, A.H.A. Assessing the effect of thyme and rosemary as antiaflatoxicosis on fertility in male rats. J. Am. Sci. 2015, 11, 294-302.

56. Skonieczna, J.; Madej, J.P.; Będziński, R. Accessory genital glands in the New Zealand White rabbit: A morphometrical and histological study. J. Vet. Res. 2019, 63, 251-257. [CrossRef]

Publisher's Note: MDPI stays neutral with regard to jurisdictional claims in published maps and institutional affiliations.

(C) 2020 by the authors. Licensee MDPI, Basel, Switzerland. This article is an open access article distributed under the terms and conditions of the Creative Commons Attribution (CC BY) license (http://creativecommons.org/licenses/by/4.0/). 